\title{
Structural and biological properties of protein hydrolysates from seafood by-products: a review focused on fishery effluents
}

\author{
Rosa Stephanie NAVARRO-PERAZA, Idalia OSUNA-RUIZ², María Elena LUGO-SÁNCHEZ, \\ Ramón PACHECO-AGUILAR ${ }^{1}$, Juan Carlos RAMÍREZ-SUÁREZ ${ }^{1}$, Armando BURGOS-HERNÁNDEZ, \\ Emmanuel MARTÍNEZ-MONTAÑO ${ }^{2,4}$, Jesús Aarón SALAZAR-LEYVA²* (D)
}

\begin{abstract}
Enormous amounts of by-products and waste are generated during the processing of seafood, sometimes representing about $65 \%$ of the raw material employed. Seafood by-products (SB) include solid waste such as skin, head, viscera, trimmings, and bones; however, liquid wastes (effluents) derived from operations such as washing, thawing, cooking and the production of fishmeal are also produced. SB contain considerable amounts of protein and others biomolecules, which has been regularly processed as food ingredients for animal nutrition. But also, sometimes SB are used as fertilizers or discarded to environment without a previous treatment. Nowadays, there is an increasing interest in adding value to the protein material within SB by improving their properties through hydrolysis and thus releasing of peptides with bioactive properties. Thus, this review aims to present an overview of the potential of SB, focused on effluents, as a source of protein hydrolysates, summarizing their methods of production, bioactive property evaluation and structural characteristics.
\end{abstract}

Keywords: seafood; effluents; by-products; hydrolysates; bioactive peptides.

Practical Application: This review provides the particularities of biological properties and structural characteristics of protein hydrolysates from solids and specially liquids seafood by-products, focusing mainly in obtaining potential bioactive peptides from fishery effluents, with the aim to enhance their valorization.

\section{Introduction}

During the processing of seafood considerable amounts of solid and liquid by-products are produced (Food and Agriculture Organization of the United Nations, 2013). Solid by-products represent about $65 \%$ of the raw material weight, which includes heads, bones, viscera, among others corporal structures (Food and Agriculture Organization of the United Nations, 2014). Besides, different effluents are produced during processing operations such as washing, thawing, cooking, and during the production of fishmeal (Ferraro et al., 2013). Two examples of fishery effluents that contain an impressive proportion of soluble nutrients, especially proteins, are stickwater and cooking water, which contains approximately 4 to $5 \%$ of proteins on a wet basis (Goycoolea et al., 1997; Hung et al., 2014).

Seafood by-products (SB) represent a potential source of functional and bioactive compounds because they contain a high amount of protein-rich material (Afonso \& Bórquez, 2002; Fjerbæk Søtoft et al., 2015); however, SB are usually discarded because of their low commercial value, and/or sanitary regulations that prohibit their use in human foods (Jędrejek et al., 2016). In the interest of promoting the use of proteins from SB, several methods have been developed to produce and recover potential bioactive compounds that can contribute to the improvement of human health (Chalamaiah et al., 2012). These methods generally include the hydrolysis of proteins by the addition of exogenous enzymes, followed by ultrafiltration to fractionate hydrolysates and to obtain bioactive peptides within a specific molecular weight range (Picot et al., 2010). Therefore, bioactive peptides derived from SB protein hydrolysates could be considered as potential valuable compounds for improving human health. This review provides an overview of the recovery of protein fractions from solid and liquid SB and waste, focused mainly in obtaining potential bioactive peptides from fishery effluents summarizing their biological properties and structural characteristics.

\section{Fishery effluents as an alternative to obtaining valuable protein compounds}

The seafood processing plants differ from one another in the raw material employed, source of processing water, the additives used and operational units involved (Cristóvão et al., 2015). Seafood processing operations produce effluents or wastewaters containing salts, soluble organic molecules, colloidal and particle forms, which are considered as potentially polluting substances, with a high content of Chemical Oxygen Demand (COD) mainly from biodegradable matter, such as proteins and lipids (Cristóvão et al., 2015).

${ }^{1}$ Centro de Investigación en Alimentación y Desarrollo - CIAD A. C., Hermosillo, Sonora, México

${ }^{2}$ Unidad Académica de Ingeniería en Biotecnología, Universidad Politécnica de Sinaloa - UPSIN, Mazatlán, Sinaloa, México

${ }^{3}$ Departamento de Investigación y Posgrado en Alimentos - DIPA, Universidad de Sonora, Hermosillo, Sonora, México

${ }^{4}$ Consejo Nacional de Ciencia y Tecnología - CONACYT, Ciudad de México, México

*Corresponding author: jsalazar@upsin.edu.mx 
From this perspective, an appropriate effluent treatment process could be applied and thus, an interesting opportunity for fishery effluents valorization could be considered. This is of great interest, aside from the high quantities generated, due to the potential recovery of valuable compounds and unique value-added products, which may result in economic and environmental benefits (Fjerbæk Søtoft et al., 2015; Cristóvão et al., 2015). At this regard, seafood processing effluents, reported as a good source of potential protein-based value-added compounds, are briefly described.

\subsection{Cooking juice}

The fish canning industry commonly uses tuna or small pelagic fish such as sardine and anchovy as raw material. During canning, several steps are involved, such as washing, thawing and cooking of the raw material, where several effluents are generated. Thus, cooking is an essential operation where an abundant effluent known as "cooking juice" or "cooking wastewater" is made. It has been reported that a fish canning plant yields approximately from 15 to $27 \mathrm{t}$ per day of cooking juice, containing about $4 \%$ of water-soluble proteins, including sarcoplasmic proteins and other proteins such as collagen (Jao \& Ko, 2002; Hsu et al., 2009). Similarly, during anchovy (Engraulis japonicus) processing, approximately $1.5 \mathrm{t}$ for each $\mathrm{t}$ of processed species of cooking wastewater is generated; furthermore, this effluent is considered an excellent nutritional resource due to its crude protein $(5 \mathrm{~g} / \mathrm{L})$ and essential amino acids content (Tang et al., 2015).

\subsection{Stickwater}

The production of fishmeal involves several steps, such as mincing, cooking, pressing, and drying of whole fish or fish by-products. After the cooking and pressing of raw material, a solid phase and a liquid are obtained. Afterward, the press liquor is centrifuged to remove the oil and an effluent named "stickwater" is derived. Stickwater (SW) represents approximately $60 \%$ of the processed fish weight, and proteins (5-9\%) are among its major components (Pacheco-Aguilar et al., 2009; Valdez-Hurtado et al., 2018). Nowadays, the fishmeal industry recovers dry matter from stickwater with an additional step of evaporation. The concentrated solids are mixed with the press cake increasing the yield of the fishmeal production. Nevertheless, in some cases fishmeal plants lack appropriate equipment to evaporate and concentrate stickwater, which implies the irregular operation of discharging the stickwater directly to the sea or coastal areas, causing a severe pollution problem (Pacheco-Aguilar et al., 2018).

As mentioned, seafood processing produces large volumes of effluents, which possess an important amount of soluble proteins that could be recovered and concentrated through different processes and could be used as raw material to produce protein hydrolysates. This fact could be considered as a strategy to add value to the fishery industry and contribute to generate economic and environmental benefits by reducing costs related to fishery effluents discharge (Figure 1).

\section{Development and isolation of bioactive peptides derived from seafood by-products protein hydrolysates}

\subsection{Enzymatic hydrolysis}

Enzymatic hydrolysis $(\mathrm{EH})$ is a process that allows a better control of the resulting hydrolysate and thereby its properties (Zamora-Sillero et al., 2018). The main variables involved in $\mathrm{EH}$ are enzyme-substrate ratio, temperature, $\mathrm{pH}$, time of incubation, the degree of hydrolysis as well as the appropriate selection of

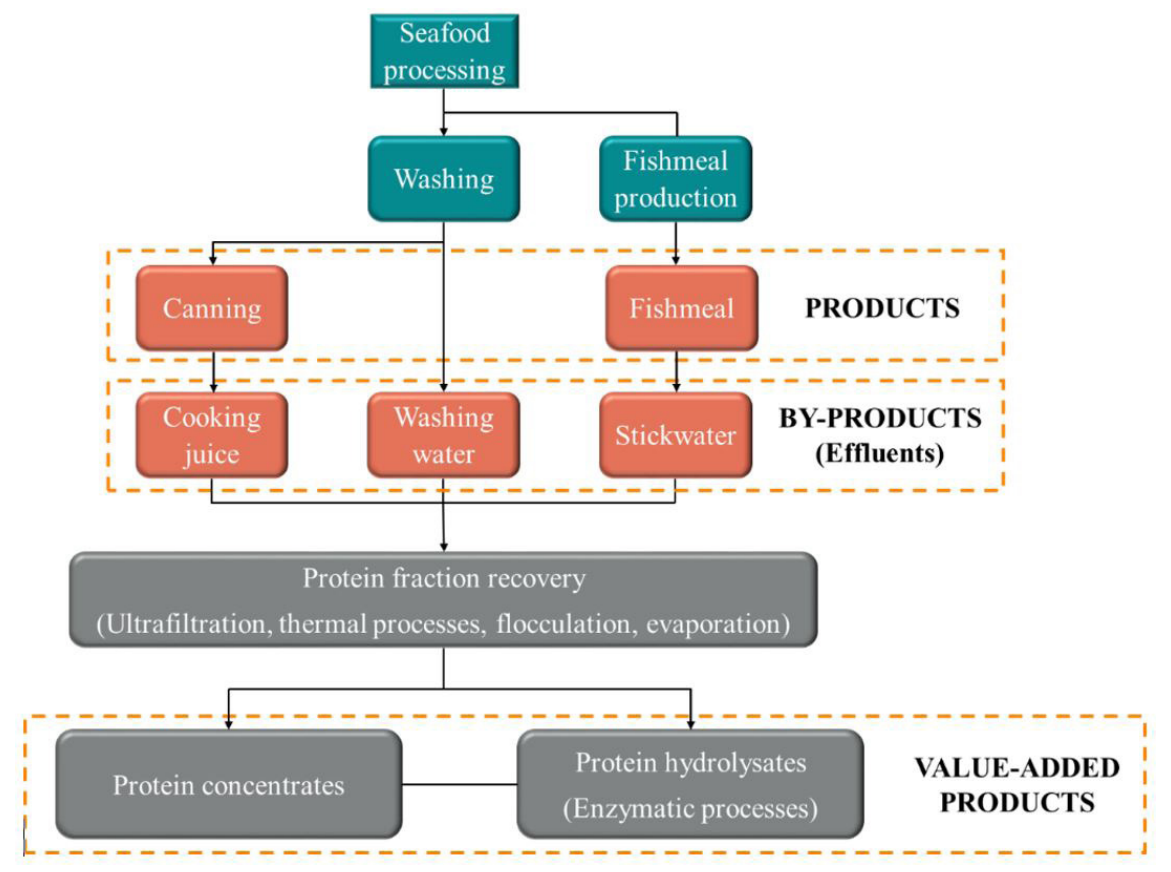

Figure 1. Fishery effluents generation and the process for their valorization and recovery of potential added-value compounds. 
the proteolytic enzyme, since its specificity influence the size and composition of peptides which in turn influence the bioactive properties of the resulting hydrolysates (Chalamaiah et al., 2012; Zamora-Sillero et al., 2018).

One of the leading established applications for $\mathrm{EH}$ that has attracted the remarkable interest of food researchers worldwide is the production of seafood by-products protein hydrolysates (SBPH) (Chalamaiah et al., 2012); which tuna (Saidi et al., 2014), tilapia (Bernardi et al., 2016; Wachirattanapongmetee et al., 2019) and salmon (Slizyte et al., 2016) are the most studied species. SBPH result from the enzymatic hydrolysis of protein-rich seafood by-products such as bones, heads, viscera, skin, and even effluents, leading to peptides of diverse sizes that exhert bioactive properties (Fernandes, 2016). Compared to solid by-products, information related to the study of fishery effluents as a source of protein hydrolysates, is scarce. For instance, wastewaters from the industrial manufacturing of tuna (Jao \& Ko, 2002; Hsu et al., 2009; Hung et al., 2014), and kilka (Mahdabi \& Hosseini Shekarabi, 2018) have been considered as a potential source of valuable compounds, such as protein hydrolysates and bioactive peptides (Table 1).

\subsection{Membrane technology}

Membrane separation technologies (MST) use hydrostatic pressure to force a liquid through a semi-permeable membrane. MST minimize protein denaturation; therefore they are useful to concentrate or fractionate valuable molecules from effluents of seafood processing industries (Bourseau et al., 2009). In this regard, MST have been used in the treatment of seafood processing effluents for the recovery of added-value value compounds such as proteins, production of fish protein concentrates and hydrolysates (Afonso \& Bórquez, 2002) and thus, obtaining peptides of specific molecular weight range that could show enhanced bioactive properties (Pan et al., 2016).

\section{Bioactive properties of seafood by-products protein hydrolysates}

\subsection{Antioxidant activity}

Oxidative damage can be triggered by the depletion of antioxidants in the organism, due to the formation of free radicals and reactive oxygen species (ROS) by physiological processes such as cellular respiration or even by exogenous molecules (Zamora-Sillero et al., 2018). Oxidative damage is mainly related to deleterious processes, such as lipid peroxidation, enzyme inactivation, protein denaturation, and DNA damage, these processes favor the frequency of several conditions such as cancer (Zamora-Sillero et al., 2018).
In this regard, impressive results related to the production of antioxidant protein hydrolysates and peptides from fishery effluents have been reported. For example, Jao \& Ko (2002) reported a high DPPH scavenging activity exhibited by a protein hydrolysate and its fraction obtained from tuna cooking juice. In a study performed by Hsu et al. (2009) found that hydrolysates from tuna cooking juice acted as retarders of lipid peroxidation.

\subsection{Antimutagenic activity}

Mutations are permanent genetic alterations which may result in heritable changes in the characteristics of the DNA sequence of a living organism, and hence the development of multiple diseases such as cancer. Mutations are mainly induced by external factors (mutagens) or even can be promoted spontaneously from errors in DNA replication, recombination and repair (Słoczyńska et al., 2014). Antimutagenic compounds prevent the interaction between a mutagen and DNA reducing the frequency of induced or spontaneous mutations and therefore delay cancer progression (Słoczyńska et al., 2014). Ames test is one of the most common methods applied to predict the antimutagenic potential of a compound through the induction of reverse mutations in histidine operon of genetically modified Salmonella typhimurium strains in the presence of a standard mutagen such as aflatoxin $\mathrm{B}_{1}\left(\mathrm{AFB}_{1}\right)$ (Maron \& Ames, 1983). However, the studies on antimutagenic activity derived from $\mathrm{SBPH}$ are minimal. Suárez-Jiménez et al. (2015) reported that collagen hydrolysates from jumbo squid by-products exhibited an effective inhibition of the induced mutation with $\mathrm{AFB}_{1}$ of $S$. typhimurium TA98 and TA100 strains. Additionally, Burgos-Hernández et al. (2016) investigated the antimutagenic potential of several fractions obtained from anchovy viscera against $\mathrm{AFB}_{1}$ using S. typhimurium TA98 and TA100 tester strains. On the other hand, several studies reported the antimutagenic activity of some compounds obtained from seafood products such as white shrimp (López-Saiz et al., 2016), octopus (Cruz-Ramírez et al., 2015), and some other marine resources such as several species of seaweed (Osuna-Ruiz et al., 2016). Nowadays, little is known about the assessment of antimutagenic activity in protein hydrolysates and peptides from fishery effluents.

\subsection{Antiproliferative activity}

Carcinogenesis involves an accumulation of mutations and increased proliferation of cells (Tanaka, 2013). In order to investigate the potential in vitro antiproliferative activity of compounds such as seafood by-products protein hydrolysates (SBPH), one of the most common methods used is the MTT assay [3-(4,5-dimethylthiazol-2-yl)-2,5-diphenyl tetrazolium bromide] assay, which is a method based on the detection of mitochondrial dehydrogenase activity, and thus, measures

Table 1. Bioactive protein hydrolysates derived from liquid seafood by-products.

\begin{tabular}{cccc}
\hline Wastewater & Method of production & Bioactivity showed & Reference \\
\hline Kilka stickwater & Alcalase & Antioxidant & Mahdabi and Hosseini Shekarabi (2018) \\
Tuna cooking juice & Protease XXIII & Antioxidant & Jao \& Ko (2002) \\
Tuna cooking juice & Orientase & Antioxidant & Hsu et al. (2009) \\
Tuna cooking juice & Protease XXIII and ultrafiltration & Antiproliferative & Hung et al. (2014) \\
\hline
\end{tabular}


cytotoxicity, proliferation and/or activation of cells (Mosmann, 1983). For instance, Hung et al. (2014) found that the $>2.5 \mathrm{kDa}$ ultrafiltration fraction from tuna cooking juice hydrolysates exhibited high antiproliferative activity against a breast cancer cell line (MCF-7) and it showed no cytotoxic effect on the cell viability of a mammary epithelial cells (MCF-10A).

\section{Relationship between structural features and bioactive properties of peptides in seafood by- products protein hydrolysates}

The biological activities of peptides in SBPH are mainly related to their structural features, such as amino acid composition, sequence, hydrophobicity, among others. Most of the isolated bioactive peptides from SBPH contain amino acid sequences ranging from 2 to 25 residues; additionally, the main amino acids of these sequences are glycine, hydrophobic amino acids such as proline, leucine, alanine, methionine, and one or more residues of arginine, aspartic acid, glutamic acid, threonine, and tyrosine (Pan et al., 2016; Abdelhedi et al., 2018).

It is considered that hydrophobic amino acids in peptide sequences contribute to scavenging free radicals through the contact with hydrophobic radical species (Pan et al., 2016). Additionally, it has been identified that the aromatic amino acids have an essential radical-scavenging effect by transferring electrons (Pan et al., 2016). Hsu et al. (2009) suggested that the highest antioxidant activity of a fraction from tuna cooking juice, could be attributed to the presence of proline and histidine residues in two characterized peptides, most probably due to their proton-donation ability of the imidazole group from histidine and sensitivity to oxygen from proline.

Additionally, Huang et al. (2011) suggested that peptides with high hydrophobicity can permeate into the hydrophobic core of the cell membrane, which might explain that hydrophobicity plays a vital role in antiproliferative activity. Hung et al. (2014) found that a $>2.5 \mathrm{kDa}$ peptide fraction from hydrolysates of tuna cooking juice composed mainly of hydrophobic amino acids showed antiproliferative activity against a breast cancer cell line. Also, the authors reported that the peptide fraction induced the expression of caspase 3 which activated apoptosis in cancer cells, and induced cell cycle arrest.

\section{Conclusion}

Several protein hydrolysates and bioactive peptides from seafood by-products with antioxidant, antimutagenic, and antiproliferative activity have been identified from different by-products that are mainly considered as wastes. Also, it has been shown that another essential source of proteins are fishery effluents, and that its recovery could increase their value as they could be a new promising source of bioactive peptides if the appropriate process of isolation is carried out.

It is known that the bioactive properties of these peptides are mainly based on several factors such as amino acid composition, sequence, and primarily the presence of hydrophobic amino acids; this knowledge could contribute to propose possible mechanisms of action. However, more studies about the structure and function of bioactive peptides are needed for better understanding the complete mechanism of action and interactions of these with other components and molecules, since they can be considered valuable compounds that can improve human health.

\section{Acknowledgements}

The authors acknowledge to Consejo Nacional de Ciencia y Tecnología (CONACYT) for financial grant No. 258128 and for the doctoral scholarship granted to Navarro-Peraza (No. 416030).

\section{References}

Abdelhedi, O., Nasri, R., Mora, L., Jridi, M., Toldrá, F., \& Nasri, M. (2018). In silico analysis and molecular docking study of angiotensin I-converting enzyme inhibitory peptides from smooth-hound viscera protein hydrolysates fractionated by ultrafiltration. Food Chemistry, 239, 453-463. http://dx.doi.org/10.1016/j.foodchem.2017.06.112. PMid:28873590.

Afonso, M. D., \& Bórquez, R. (2002). Review of the treatment of seafood processing wastewaters and recovery of proteins therein by membrane separation processes - prospects of the ultrafiltration of wastewaters from the fish meal industry. Desalination, 142(1), 29-45. http://dx.doi.org/10.1016/S0011-9164(01)00423-4.

Bernardi, D. M., Paris, L. D., Dieterich, F., Silva, F. G. D., Boscolo, W. R., Sary, C., Signor, A., Bertol, T. M., \& Sgarbieri, V. C. (2016). Production of hydrolysate from processed Nile tilapia (Oreochromis niloticus) residues and assessment of its antioxidant activity. Food Science and Technology (Campinas), 36(4), 709-716. http://dx.doi. org/10.1590/1678-457x.15216.

Bourseau, P., Vandanjon, L., Jaouen, P., Chaplain-Derouiniot, M., Massé, A., Guérard, F., Chabeaud, A., Fouchereau-Péron, M., Le Gal, Y., Ravallec-Plé, R., Bergé, J.-P., Picot, L., Piot, J.-M., Batista, I., Thorkelsson, G., Delannoy, C., Jakobsen, G., \& Johansson, I. (2009). Fractionation of fish protein hydrolysates by ultrafiltration and nanofiltration: impact on peptidic populations. Desalination, 244(1-3), 303-320. http://dx.doi.org/10.1016/j.desal.2008.05.026.

Burgos-Hernández, A., Rosas-Burgos, E.-C., Martínez, M., NuncioJauregui, P.-N., Marhuenda, F., Kačániová, M., Petrová, J., \& Carbonell-Barrachina, A.-A. (2016). Bioactive fractions from cantabrian anchovy (Engraulis encrarischolus) viscera. Food Science and Technology (Campinas), 36(3), 426-431. http://dx.doi. org/10.1590/1678-457X.10115.

Chalamaiah, M., Dinesh Kumar, B., Hemalatha, R., \& Jyothirmayi, T. (2012). Fish protein hydrolysates: Proximate composition, amino acid composition, antioxidant activities and applications: a review. Food Chemistry, 135(4), 3020-3038. http://dx.doi.org/10.1016/j. foodchem.2012.06.100. PMid:22980905.

Cristóvão, R. O., Botelho, C. M., Martins, R. J. E., Loureiro, J. M., \& Boaventura, R. A. R. (2015). Fish canning industry wastewater treatment for water reuse - a case study. Journal of Cleaner Production, 87, 603-612. http://dx.doi.org/10.1016/j.jclepro.2014.10.076.

Cruz-Ramírez, S.-G., López-Saiz, C.-M., Rosas-Burgos, E.-C., CincoMoroyoqui, F.-J., Velázquez, C., Hernández, J., \& Burgos-Hernández, A. (2015). Antimutagenic, antiproliferative, and antioxidant effect of extracts obtained from octopus (Paraoctopus limaculatus). Food Science and Technology (Campinas), 35(4), 722-728. http://dx.doi. org/10.1590/1678-457X.0001.

Fernandes, P. (2016). Enzymes in Fish and Seafood Processing. Frontiers in Bioengineering and Biotechnology, 4(59). http://dx.doi.org/10.3389/ fbioe.2016.00059.

Ferraro, V., Carvalho, A. P., Piccirillo, C., Santos, M. M. L., Castro, P. M. E., \& Pintado, M. E. (2013). Extraction of high added value biological compounds from sardine, sardine-type fish and mackerel 
canning residues - A review. Materials Science and Engineering $C$, 33(6), 3111-3120. http://dx.doi.org/10.1016/j.msec.2013.04.003. PMid:23706190.

Fjerbæk Søtoft, L., Lizarazu, J. M., Razi Parjikolaei, B., Karring, H., \& Christensen, K. V. (2015). Membrane fractionation of herring marinade for separation and recovery of fats, proteins, amino acids, salt, acetic acid and water. Journal of Food Engineering, 158, 39-47. http://dx.doi.org/10.1016/j.jfoodeng.2015.02.020.

Food and Agriculture Organization of the United Nations - FAO. (2013). Innovative uses of fisheries by-products. Rome: FAO. GLOBEFISH.

Food and Agriculture Organization of the United Nations - FAO. (2014). El estado mundial de la pesca y la acuicultura: oportunidades $y$ desafíos. Roma: FAO.

Goycoolea, F. M., Nieblas, J. M., Noriega, L. O., \& Higuera-Ciapara, I. (1997). Temperature and concentration effects on the flow behaviour of stickwater. Bioresource Technology, 59(2-3), 217-225. http://dx.doi. org/10.1016/S0960-8524(96)00145-9.

Hsu, K.-C., Lu, G.-H., \& Jao, C.-L. (2009). Antioxidative properties of peptides prepared from tuna cooking juice hydrolysates with orientase (Bacillus subtilis). Food Research International, 42, 647652. http://dx.doi.org/10.1016/j.foodres.2009.02.014.

Huang, Y., Wang, X., Wang, H.-y., Liu, Y., \& Chen, Y. (2011). Studies on mechanism of action of anticancer peptides by modulation of hydrophobicity within a defined structural framework. Molecular Cancer Therapeutics, 10(3), 416-426. http://dx.doi.org/10.1158/15357163.MCT-10-0811. PMid:21252288.

Hung, C.-C., Yang, Y.-H., Kuo, P.-F., \& Hsu, K.-C. (2014). Protein hydrolysates from tuna cooking juice inhibit cell growth and induce apoptosis of human breast cancer cell line MCF-7. Journal of Functional Foods, 11, 563-570. http://dx.doi.org/10.1016/j.jff.2014.08.015.

Jao, C.-L., \& Ko, W.-C. (2002). 1,1-Diphenyl-2-picrylhydrazyl (DPPH) radical scavenging by protein hydrolyzates from tuna cooking juice. Fisheries Science, 68(2), 430-435. http://dx.doi.org/10.1046/j.14442906.2002.00442.x.

Jędrejek, D., Levic, J., Wallace, J., \& Oleszek, W. (2016). Animal byproducts for feed: characteristics, European regulatory framework, and potential impacts on human and animal health and the environment. Journal of Animal and Feed Sciences, 25(3), 189-202. http://dx.doi. org/10.22358/jafs/65548/2016.

López-Saiz, C.-M., Hernández, J., Cinco-Moroyoqui, F.-J., Velázquez, C., Ocaño-Higuera, V.-M., Plascencia-Jatomea, M., Robles-Sánchez, M., Machi-Lara, L., \& Burgos-Hernández, A. (2016). Antimutagenic compounds of white shrimp (Litopenaeus vannamei): isolation and structural elucidation. Evidence-Based Complementary and Alternative Medicine, 2016, 8148215. http://dx.doi.org/10.1155/2016/8148215. PMid:27006678.

Mahdabi, M., \& Hosseini Shekarabi, S. P. (2018). A comparative study on some functional and antioxidant properties of kilka meat, fishmeal, and stickwater protein hydrolysates. Journal of Aquatic Food Product Technology, 27(7), 844-858. http://dx.doi.org/10.108 0/10498850.2018.1500503.

Maron, D. M., \& Ames, B. N. (1983). Revised methods for the Salmonella mutagenicity test. Mutation Research, 113(3-4), 173-215. http:// dx.doi.org/10.1016/0165-1161(83)90010-9. PMid:6341825.

Mosmann, T. (1983). Rapid colorimetric assay for cellular growth and survival: Application to proliferation and cytotoxicity assays. Journal of Immunological Methods, 65(1-2), 55-63. http://dx.doi. org/10.1016/0022-1759(83)90303-4. PMid:6606682.

Osuna-Ruiz, I., López-Saiz, C.-M., Burgos-Hernández, A., Velázquez, C., Nieves-Soto, M., \& Hurtado-Oliva, M. A. (2016). Antioxidant, antimutagenic and antiproliferative activities in selected seaweed species from Sinaloa, Mexico. Pharmaceutical Biology, 54(10),
2196-2210. http://dx.doi.org/10.3109/13880209.2016.1150305. PMid:26959892.

Pacheco-Aguilar, R., Calderón de la Barca, A. M., Castillo-Yañez, F. J., Márquez-Ríos, E., García-Carreño, F. L., \& Valdez-Hurtado, S. (2018). Comparación del efecto de dos tratamientos enzimáticos con actividad colagenasa y una centrifugación complementaria en las características fisicoquímicas del agua de cola generada por la industria pesquera sardinera. Biotecnia, XX(3), 58-64.

Pacheco-Aguilar, R., Leyva-Soto, P., Carvallo-Ruiz, G., García-Carreño, L. F., \& Márquez-Ríos, E. (2009). Efecto de la concentración de quitosano y $\mathrm{pH}$ sobre la remoción de sólidos de agua de cola de la industria sardinera. Interciencia, 34(4), 274-279.

Pan, X., Zhao, Y.-Q., Hu, F.-Y., \& Wang, B. (2016). Preparation and identification of antioxidant peptides from protein hydrolysate of skate (Raja porosa) cartilage. Journal of Functional Foods, 25, 220230. http://dx.doi.org/10.1016/j.jff.2016.06.008.

Picot, L., Ravallec, R., Fouchereau-Péron, M., Vandanjon, L., Jaouen, P., Chaplain-Derouiniot, M., Guérard, F., Chabeaud, A., LeGal, Y., Alvarez, O. M., Bergé, J. P., Piot, J. M., Batista, I., Pires, C., Thorkelsson, G., Delannoy, C., Jakobsen, G., Johansson, I., \& Bourseau, P. (2010). Impact of ultrafiltration and nanofiltration of an industrial fish protein hydrolysate on its bioactive properties. Journal of the Science of Food and Agriculture, 90(11), 1819-1826. http://dx.doi.org/10.1002/jsfa.4020. PMid:20602518.

Saidi, S., Deratani, A., Belleville, M.-P., \& Amar, R. B. (2014). Production and fractionation of tuna by-product protein hydrolysate by ultrafiltration and nanofiltration: Impact on interesting peptides fractions and nutritional properties. Food Research International, 65, 453-461. http://dx.doi.org/10.1016/j.foodres.2014.04.026.

Slizyte, R., Rommi, K., Mozuraityte, R., Eck, P., Five, K., \& Rustad, T. (2016). Bioactivities of fish protein hydrolysates from defatted salmon backbones. Biotechnology Reports (Amsterdam, Netherlands), 11, 99109. http://dx.doi.org/10.1016/j.btre.2016.08.003. PMid:28352546.

Słoczyńska, K., Powroźnik, B., Pękala, E., \& Waszkielewicz, A. M. (2014). Antimutagenic compounds and their possible mechanisms of action. Journal of Applied Genetics, 55(2), 273-285. http://dx.doi. org/10.1007/s13353-014-0198-9. PMid:24615570.

Suárez-Jiménez, G. M., Robles-Sánches, R. M., Yépiz-Plascencia, G., Burgos-Hernández, A., \& Ezquerra-Brauer, J. M. (2015). In vitro antioxidant, antimutagenic and antiproliferative activities of collagen hydrolysates of jumbo squid (Dosidicus gigas) byproducts. Food Science and Technology (Campinas), 35(3), 421-427. http://dx.doi. org/10.1590/1678-457X.6658.

Tanaka, T. (2013). Role of apoptosis in the chemoprevention of cancer. Journal of Experimental and Clinical Medicine, 5(3), 89-91. http:// dx.doi.org/10.1016/j.jecm.2013.04.001.

Tang, W., Zhang, H., Wang, L., Qian, H., \& Qi, X. (2015). Targeted separation of antibacterial peptide from protein hydrolysate of anchovy cooking wastewater by equilibrium dialysis. Food Chemistry, 168, 115-123. http://dx.doi.org/10.1016/j.foodchem.2014.07.027. PMid:25172690.

Valdez-Hurtado, S., Goycolea-Valencia, F., Márquez-Ríos, E., \& PachecoAguilar, R. (2018). Efecto de una centrifugación complementaria en la composición química y reológica del agua de cola. Biotecnia, $\mathrm{XX}(2), 95-103$.

Wachirattanapongmetee, K., Katekaew, S., Sae-eaw, A., \& Thawornchinsombut, S. (2019). Production factors affecting antioxidant peptides from tilapia processing byproducts. Food Science and Technology (Campinas), 39(1), 181-187. http://dx.doi.org/10.1590/fst.00218.

Zamora-Sillero, J., Gharsallaoui, A., \& Prentice, C. (2018). Peptides from fish by-product protein hydrolysates and its functional properties: an overview. Marine Biotechnology (New York, N.Y.), 20(2), 118-130. http://dx.doi.org/10.1007/s10126-018-9799-3. PMid:29532335. 